International Journal of English Literature and Social Sciences
Vol-7, Issue-1; Jan-Feb, 2022
Journal Home Page Available: https://ijels.com/
Journal DOI: $10.22161 /$ ijels

Peer-Reviewed Journal

\title{
Critiquing Colonialism and Middle-Class Dominance - A Postcolonial Study of Six Acres and a third
}

\author{
Soumyakanta Senapati
}

Research Scholar, Department of Humanistic Studies, Indian Institute of Technology (BHU), Varanasi, India

Received: 18 Dec 2021; Received in revised form: 25 Jan 2022; Accepted: 03 Feb 2022; Available online: 08 Feb 2022 C 2022 The Author(s). Published by Infogain Publication. This is an open access article under the CC BY license (https://creativecommons.org/licenses/by/4.0/).

\begin{abstract}
The intervention of colonial laws and administration in the indigenous society of Odisha caused a lot of upheavals in the native's life. Along with the colonizers, the middle-class people also took advantage of the laws to exploit the innocent and illiterate lower class Odias. Fakir Mohan Senapati's path-breaking novel Six Acres and a Third skilfully mirrors this impact of Colonial intervention in Odia society. By giving a vivid picture of Colonialism and middle class dominance and oppression, Senapati exposes the system of his day and presents it in a satiric manner as an act resistance. The novel, providing a micro picture of Colonialism and oppression of natives by the middle class people like Zamindars and Lawyers, depicts a number of social issues and implicitly critiques the whole system.
\end{abstract}

Keywords-colonialism, postcolonial studies, middle-class, dominance, Odia society, culture, Fakir Mohan Senapati, Chha Mana Atha Guntha.

\section{INTRODUCTION}

Postcolonial studies, as a distinct field of academic inquiry, emerged in the last quarter of twentieth century. It shows the after effects of Colonialism and critiques its several dimensions. Colonialism, in simple terms, is the conquest and control of goods and land of people in a foreign territory. The root word of "Colonialism" is 'Colony' which is derived from the Latin word 'Colonia'. It means 'farms or landed estates' which were located $\mathrm{n}$ the newly conquered territory of Roman Empire. In the time of Roman Empire, the veteran soldiers were given lands in the newly conquered territories as reward for their service. They used to move to that territory, settle there, and control the territory with power, exploiting its resources in the interest of the mother country at the same time. So, the process of colonialism involves forcibly occupation of land and other resources. Though Colonialism of ancient or middle Ages included only physical violence, the modern day colonialism, which is a capitalism driven enterprise, also includes cultural and economic violence by the colonizers on natives. Alongside the large scale exploitation of physical resources, it also destroyed the native tradition and brought its own laws and administrative policies to control and manage the governance of the colonial state. With time, it bestowed more power in the hands of the middle class which was native by birth but English in taste, opinion, and attitude and empowered with colonial agency. This conjunction of British colonialism and middle class dominance was at the heart of Colonial process in India and it contributed a great deal to the exploitation of lower class natives and disintegration of their society. So, in this context, Postcolonial studies seeks to address and critique various social, political, economic and cultural effects of Colonialism. Fakir Mohan Senapati's seminal postcolonial text Chha Mana Atha Guntha, translated into English as Six Acres and a Third, explores the social, economic, and cultural effects of Colonialism on Odia society. 


\section{DISCUSSION}

Before the intrusion of Colonial powers, Odisha was a land of unique culture and tradition and was thriving politically, economically, socially and culturally. But with the advent of colonialism, under the veil of civilizing mission, in the beginning of nineteenth century, the western culture and modern civilization exerted a negative influence on the life and culture of Odisha, either through direct colonial administration or through the middle class empowered with colonial agency. It affected the life of the masses adversely and resulted in the erosion of a unique way of life. While the middle class joined hands with the colonizers and got empowered with agency, the most affected were the Odia lower class people. In view of their backwardness, they merited the attention of the colonizer; the Colonizers brought laws, policies etc, snatched the profession and possessions of the natives, and displaced them to a subordinate status. The middle class acted as a mediating agent and started using the colonial laws to exploit the people. The exotic laws, the alien administration, and the middle class exploitation made the life of lower class people even more pathetic. These concerns have been aptly depicted in Six Acres and a Third, a path-breaking work in Odia literature. The novel is multidimensional in nature and addresses a number of social issues of the time. As the title suggests, the novel tells the tragic tale of the illegal acquisition of the fertile land of a peasant couple through manipulation. On the other hand, the novel also provides a moving microcosmic picture of Colonial system of those days and the middle class dominance that arose alongside colonialism; and at the same time it criticizes the alien colonial laws that were the cause of misery for the illiterate indigenous people.

\section{A CRITIQUE OF COLONIALISM}

Senapati hasn't presented the adverse effects of Colonialism in an explicit manner, nor has he directly criticized the colonial laws. It may be because he was working in the colonial system and was in a hybrid position of native and colonial identity, he didn't launch a frontal attack on his colonial masters. So, instead of unleashing a direct attack on the Colonial administration, he does it, through his ambivalent advocacy, in a satiric manner by directing his attack towards the middle class. The novel presents a replica of the colonialism in a microcosmic manner. The protagonist of the novel Ramachandra Mangaraj, a despotic and evil landlord, is the colonizer who through various means exploit people, occupy their property and controls the village. Colonialism, as Loomba remarks, is the forcibly takeover of land and economy. In the village Gobindapur, Mangaraj, as a colonizer, occupies land of the poor peasant couple through his narrative and exertion of power. He also controls the village economy which is evident from the single fact that "the market in Gobindapur owed its existence and prosperity to him" (Mishra 42) and the vendors cannot sell their vegetables until the vegetables of Mangaraj's orchard has not all been sold. Mangaraj, as a colonizer, has his own colonial agents like his servantcum-mistress champa and Gobinda and he runs the empire both by consent and by coercion.

Though the novel doesn't carry any apparent or overt mention of the draconian colonial laws except during the investigation of the Police and the court proceedings, they are actually at the root of the sufferings shown in the novel and under attack of Senapati's covert criticism. The unstable political system in Odisha invited the British to establish stable governance and to carry forward their civilizing mission. The British intervened and changed the political and social structure of Odisha. They promulgated several laws like Permanent Settlement act, tax system etc that gave power in the hands of the middle class zamindars through whom the British remotely controlled the areas. Loomba says:

Colonial administration in this case functioned to a large extent through colonial authorities and existing power structures. They incorporated rather than disturbed native hierarchies...taxes were collected through hereditary Indian collectors who were liable for a fixed sum as laid down in the 'Permanent Settlement' of 1793. Millions of Indians never saw an English Person throughout the term of the Raj, although that did not mean their lives had not been woven into the fabric of empire. (23-24)

We don't find any British colonizer in the novel; however, Senapati has portrayed Mangaraj as a colonial agent through whom the British run their empire remotely. Mangaraj uses both the laws and the loopholes in the laws to suppress and oppress the people in his Zamindari. Evidently, the Colonial laws affected the Odia society and lower class people adversely; the people couldn't cope with the sudden leap from a native governance system to a totally alien one. The British revenue system made land a commodity, an object of buying and selling. This resulted in the occupation of land by Zamindars when the people couldn't pay off their loan. Mangaraj occupies the land of his cousin brother, of Bhagia, and of many more through this means. They mortgage their land and are never able to pay off the loan due to the interest system; the land is then legally occupied by Mangaraj. On the contrary, the Zamindars were not spared from the colonial laws even. The sunset laws, the auctioning off of Zamindari of the 
defaulter Zamindars, also led to losing of their ancestral Zamindari in some cases. Ramachandra Mangaraj in the novel acquired the Zamindari of Fatehpur Sarsandha through this means when Dilabar Mian couldn't pay the required amount. So, even though the middle class enjoyed the power, they were not even spared from the colonial laws. The alien laws and culture of the colonizers impacted every sphere of the society negatively.

\section{THE MIDDLE-CLASS DOMINANCE}

The novel primarily shows the dominance and oppression of the middle class that emerged along with the British colonizers, though subservient to them. This is a new middle class that arose with the advent of colonialism, educated and equipped with modern colonial laws, and driven by a desire of wealth accumulation and upward social mobility. Being insiders they took advantage of the colonial laws and the loopholes of the Odia society and exploited the people. Guha divides the colonial-era elite into three different groups: the "dominant foreign groups," the "dominant indigenous groups," and lower-level "social strata," who acted in the interests of the elite. The dominant indigenous groups comprised the dominant middle class people who had access to hegemony and state power by virtue of their wealth, education or association with British officials. They enjoyed political, economic, and social agency too. The class distinction of the colonized society is aptly portrayed in the chapter named "Asurapond":

Four Kaduakhumpi birds... are happy and excited because they are able to spear and eat the little fish that live in the mud.... Some sixteen to twenty cranes, white and brown, churn the mud like lowly farmhands, from morning till night. This is the third proof that there are fish in the pond. A pair of Kingfishers suddenly arrives out of nowhere, dive into the water a couple of times, stuff themselves with food, and swiftly fly away. Sitting on the bank, a lone kingfisher suns itself, wings spread like the gown of memsahib. Oh, stupid hindu cranes, look at these English Kingfishers, who arrive out of nowhere with empty pockets, fill themselves with all manner of fish from the pond, and then fly away. You nest in the banyan tree near the pond but after churning the mud and water all day long, all you get are a few miserable small fish. You are living in critical times now; more and more kingfishers will swoop down on the pond and carry off the best fish. You have no hope, no future, unless you go abroad and learn how to swim in the ocean. (Mishra 103-104)
Picturizing the whole Odia society under colonial rule and its hierarchical system in a single paragraph, Senapati states that the Odia lower class people are the Kaduakhumpi birds who are suppressed both by middle class people or cranes and by the British colonizers or Kingfishers. Almost the same system of division is later reflected in the Subaltern Studies collective project. The Odia middle class people also designed themselves after the colonizer and started oppressing people of their own society. This was not the era of humanity or civility that the Odia society once characterized. Rather it is the era of colonialism and capitalism. The middle class here is devoid of any sympathy. Fanon says, the middle class acquired the power and agency of the colonizer after they left. But the middle class dominance actually emerged in the era of colonialism itself and acted in line with the administration. Mangaraj in the novel is vested with the colonial power and agency and oppress the people for his own interest. He casts his money lending net to trap the lower class people and exploits them when they are unable to pay the interest, which becomes even more than the principal itself in a shorter period of time. Mangaraj orders his two servants to strip the field of Shyam Gochhaita when he is in need of the seedlings and Shyam can't even protest as he owes a loan to Mangaraj. He occupies the land and property of people, even of his kins, destroys families, oppresses the poor people of the village and so continues his list of exploitation. Well aware of the laws and rules of colonial administration, Mangaraj knows how to use new legal system to grab and appropriate other's land and property. Through manipulation, he convinces the poor weaver couple Bhagia and Saria to mortgage their land and take loan from him. And when Bhagia and Saria fail to repay the loan, he uses the colonial legal system to occupy the property of the couple. As a typical middle class exploiter of colonial era and devoid of any kind of sympathy, he subjects the couple to terrible sufferings.

In the social hierarchy, the people of upper level always manipulated the people of the lower level through colonial laws. So if Mangaraj manipulates the peasant couple through the laws, then he is also manipulated by the lawyer. Senapati has also presented Mangaraj as a victim and the Lawyer as a cunning middle class oppressor to show how the lawyers used to exploit the people in Colonial Odisha and how even the middle class people weren't spared from their treachery. Owing to his job as a Dewan in different Zamindaris, he was well-acquainted with the Lawyers and their malevolence. Lawyers in Colonial India were part of the Indigenous middle class and also enjoyed greater colonial agency. Study of law and the lawyer profession came to India as colonial imports. Eventually India saw a huge fraternity of lawyers and they, 
taking advantage of the colonial laws, started exploiting the poor and the people lower to them in social strata. Gandhi said that Lawyers have enslaved India and this profession teaches immorality.

Some families have been ruined through them, they have made brothers enemies. Principalities, having come under the lawyers' power, have become loaded with debt. Many have been robbed of their all. Such instances can be multiplied. But the greatest injury they have done to the country is that they have tightened the English grip. (45-46)

The novelist also remarks "Commerce makes your rich; a bachelor's degree in laws does too, though in somewhat less so"( Mishra 45). Lawyer profession was a profitable profession at that time. Mangaraj takes help of the law court and lawyer to manipulate the poor peasant couple and occupy their land. Similarly, when Mangaraj's trial is on, it is the lawyer Ram Ram lala who manipulates Mangaraj and takes over his property. Such cunning the lawyers were that, while manipulating Mangaraj, "it took him a mere two hours to purchase the stamps, write out the mortgage deed, and get it registered" (Mishra 174). He even doesn't try much to defend Mangaraj's case.

\section{CONCLUSION}

Senapati, with his profound writing technique and power of language, gives a truthful account of the society of his day showing how the colonial system has deep penetrated in the society and how the higher class people exploits the poor. Though written at a time when middle class discourse was justifying colonial presence and the civilizing mission, Senapati's novel carries a critique of the Colonial system as well as the middle class dominance. He exposes the loopholes in the Odia society and shows how the colonial administration together with the middle class oppresses the innocent villagers disinheriting and dispossessing them from their possessions. In the end, the novel presents the universal law of Colonialism i.e with the end of one colonial power, there emerges another and the colonial dominance and oppression will continue this way.

\section{REFERENCES}

[1] Fanon, Frantz. The Wretched of the Earth. Penguine Classics, 2001.

[2] Gandhi, Mahatma. Hind Swaraj. Centenary ed, Rajpal \& Sons, 2009

[3] Loomba, Ania. Colonialism/Postcolonailism. Third ed, Routledge, 2015.

[4] Roosa, John. "When the Subaltern Took the Postcolonial Turn." Journal of the Canadian Historical Association/ Revue de la Société historique du Canada, vol.17, no. 2,
2006, pp.130-147. Érudit, http://id.erudit.org/iderudit/016593ar.

[5] Senapati, Fakir Mohan. Six Acres and a Third. Translated by Rabi Shankar Mishra et al., Penguin Books India, 2006. 